\title{
Effects of Advertising and R\&D Expenditure on Enterprise Performance
}

_-An Empirical Analysis Based on Listed Companies in China

\author{
Jiuyi Huang \\ Sichuan University Chengdu China \\ 85792782@qq.com
}

Keywords :Advertising expenditure. R\&D expenditure. Short-term profitability - Long-term value

\begin{abstract}
Based on data of Chinese companies listed between 2010 and 2012, this paper tests the effect of advertising and $R \& D$ expenditure on enterprise performance. We find that advertising expenditure has no significant impact on enterprises' short-term profitability, but it is positively correlated with enterprises' long-term value. R\&D expenditure is positively correlated with enterprises' short-term profitability, but has no significant impact on enterprises' long-term value. We also find that advertising expenditure and $R \& D$ expenditure has an interactive effect on enterprises' short-term profitability, but no significant interactive effect on enterprises' long-term value.
\end{abstract}

\section{Introduction}

In recent decades, China's economy has witnessed significant technology improvement and rapid globalization. Enterprises have to strengthen their competitive edge in order to survive. Intangible assets are seen as the major resources of competitive edge, and advertising and R\&D, as the most two important ways to play the function of corporate marketing and innovation, are two basic elements to form intangible assets. R\&D activities help enterprises develop more efficient technologies and deliver better products, and advertising can transmit the advantages of new products or new technologies to target customer more effectively, thereby increasing the sales of products or services. R\&D expenditure enhances enterprises' independent innovation capability and advertising expenditure reflects enterprises' emphasis on marketing, which respectively represent the capacity of value creation and value realization. Therefore, the impact of advertising and R\&D expenditure on financial performance has an important theoretical and practical implication. Available literature tend to study the effect of advertising or R\&D on corporate performance separately, while few literature treat them together and a handful of literatures explore the interactive effects of advertising and R\&D on firm performance.

As two main means to increase intangible assets and enhance competitiveness, what role does advertising and R\&D expenditure play in improving enterprise performance? How do they impact on enterprises' short-term and long-term performance? What's the relation between them? This 
paper will explore these issues, and our study may enrich the existing literature and provide a meaningful reference for enterprises' strategic decisions.

\section{Literature Review and Theoretical Analysis}

\subsection{Advertising, R\&D and Enterprise Performance}

Most researches test the relationship between advertising and enterprise performance or the relationship between $R \& D$ and enterprise performance separately, and find that while both have positive impact on performance, the impact on short-term profitability was not as large as on long-term performance. A few literatures analyzed the impact both of advertising and R\&D on corporate performance and came up with some interesting findings. For example, Andras and Srinivasan looked at the manufacturing and consumable industry and found that both advertising intensity and R\&D intensity had a significant impact on enterprises' gross margin[1]].

Like foreign studies, most domestic literatures treat the relation between advertising and performance or R\&D and performance separately. But these studies are limited by incomplete information disclosure on advertising and R\&D expenditure. For advertising expenditure and enterprise performance, Huang L suggested that advertising intensity had a negative impact on enterprise performance[4]; While Cheng M D showed that advertisements would shorten sales cycle and raise enterprises' operating performance[2].Jiang Y Q analyzed listed real estate companies and found that advertising expenditure had little impact on performance[5];Zhang $\mathrm{C}$ found that advertising expenditure of automobile industry had the effect of diminishing returns on sales [15]. As for R\&D expenditure and corporate performance, Li T, Huang X B and Wang C showed that $R \& D$ expenditure of information and manufacturing companies had no obvious correlation with profitability, but has a significant positive correlation with growth ability of the two industries []ㅜ; Ren H Y and Shi P confirmed R\&D expenditure of manufacturing companies had a significant positive impact on enterprise performance [9]; You C made an empirical study on small and medium-sized enterprises in Shenzhen stock market, found that R\&D expenditure was not related to return on equity and EPS [14]; Du Y P and Wang L studied 118 high-tech growth companies on SME board, the empirical results showed that $R \& D$ expenditure had a significant positive impaction sales growth and profit [3]].

Chinese enterprises are generally weak in innovation capacity. Instead of pursuing independent innovation, Chinese enterprises prefer to improving visibility by advertising in a competitive market environment. Even if they choose R\&D activities, Chinese enterprises tend to choose applied R\&D, focusing on the change of product appearance or change of production process for the purpose of reducing the cost. That is to say, short-term profitability caused by $R \& D$ expenditure will not necessarily improve enterprises' market value. Advertising is playing an increasingly important role in market competition. Based on above analysis, we put forward the following hypothesis: 
Hypothesis $1 \mathrm{R} \& \mathrm{D}$ expenditure has a positive impact on short-term profitability, but no impact on long-term value; Advertising expenditure has a positive impact on both short-term profitability and long-term value.

\subsection{The Interaction of Advertising and $R \& D$}

There are a small amount of studies on the relationship between advertising, R\&D and enterprise performance in China. Early, scholars just made comparative studies about the impact of advertising and $\mathrm{R} \& \mathrm{D}$ on enterprise performance. $\mathrm{Xu} \mathrm{J} \mathrm{Y} \mathrm{showed} \mathrm{that} \mathrm{R \& D} \mathrm{expenditure} \mathrm{had} \mathrm{a} \mathrm{causal}$ relationship with the value of electronic manufacturing companies, and advertising expenditure had no causal relationship with the value of companies in all industries [13];Wang R X studied 12 listed manufacturing companies in Taiwan, finding that advertising and $R \& D$ had a significant positive impact on enterprise excess surplus, and R\&D expenditure had greater impact than advertising [12]; Based on a sample of listed companies, the empirical research carried out by Sun W F and Huang Z $\mathrm{H}$ showed that positive correlation between R\&D expenditure and enterprise performance only existed in small enterprises while large enterprises had positive correlation between advertising expenditure and enterprise performance[10]. In recent years, there have been a small amount of research about the interactive effects between advertising and $R \& D$ investment on enterprise performance. Based on data in GEM, Liu X Y discovered that impacts of technology innovation and marketing on corporate profits were substitutable and lacking of positive synergies [7]; Qin $\mathbf{J}$ pointed out that marketing resources and technical resources would generate complementary effect when entrepreneurial enterprises launch gradual new products in mature market, and generate substitution effect when launch breakthrough products in emerging market []]

Different from disruptive innovation, incremental innovation is a minor improvement and adjustment of existing products and technologies and an incremental innovation based on existing knowledge and resources [11]. Chinese enterprises' applied R\&D investment, advertising and R\&D investment might show a complementary relation within this context. After product and technology improvement, enterprises expand awareness and increase sales in short term rapidly by advertising but this interaction is embodied mainly in enterprises' short-term profitability. In the long term, it is easily copied and hard to get market recognition without real independent innovation. Therefore, the complementarity between R\&D and advertising is difficult shown in Chinese enterprises' long-term value. Based on above analysis, we put forward the following hypothesis:

Hypothesis 2 The interaction of R\&D and advertising is positively related to enterprises' short-term profitability and has no impact on enterprises' long-term value.

\section{Research Design}

We do the empirical study from two aspects. First, we study how advertising expenditure and 
R\&D expenditure will impact on short-term profitability and long-term value respectively, then, we bring in cross term of advertising and R\&D to study the interaction effect.

\section{1 Data}

Our data are from listed companies in Shenzhen and Shanghai stock markets whose R\&D expenditure information is disclosed in the annual reports from 2010 to 2012. To guarantee the continuity of the data, we finally get 301 companies and a total of 903 observations for three years after deleting the companies whose financial data are incomplete. The other data is from CSMAR.

\section{2 Variables}

\subsubsection{The Measurement of Short-term Profitability and Long-term Value}

R\&D expenditure mainly affects operating income and operating cost, considering its purpose to improve the innovation ability. It increases the sales by designing new products, or reduces the product cost through a better process. Therefore, we choose the current gross profit margin to measure short-term profitability, the explained variable is defined as (operating income - operating cost）/ operating income. In this paper we use the Tobin Q that lagged one year relative to $R \& D$ expenditure due to information asymmetry.

\subsubsection{Explanatory Variable and Control Variable}

We define $\mathrm{RD}, \mathrm{AD}$ and their interaction as $\mathrm{R} \& \mathrm{D}$ expenditure to operating income ratio, advertising expenditure to operating income ratio and RD*AD. Based on previous studies, we take LEV, SIZE and ROA as the control variables. In addition, the nature of enterprise is introduced as virtual variable that set itself up as 1 when the enterprise is private, 0 otherwise. And the effect of time and effect of industry are controlled. Specific definitions of the variables are shown in Table 1. 
Table 1 Variable Definition

\begin{tabular}{|c|c|c|c|}
\hline \multicolumn{3}{|c|}{ Variable } & Definition \\
\hline \multirow[t]{2}{*}{$\begin{array}{l}\text { Explained } \\
\text { Variable }\end{array}$} & GPM & Gross profit margin & $\begin{array}{l}\text { (Operating income -Operating cost) } \\
\text { /Operating income }\end{array}$ \\
\hline & $\begin{array}{l}\text { Tobin } \\
\text { Q }\end{array}$ & Tobin Q & Market value /Replacement cost \\
\hline \multirow{2}{*}{$\begin{array}{c}\text { Explanatory } \\
\text { Variable }\end{array}$} & RD & R\&D intensity & R\&D expenditure / Operating income \\
\hline & $\mathrm{AD}$ & Advertising intensity & $\begin{array}{l}\text { Advertising expenditure / Operating } \\
\text { income }\end{array}$ \\
\hline \multirow{6}{*}{$\begin{array}{l}\text { Control } \\
\text { Variable }\end{array}$} & LEV & Debt Asset ratio & Total liabilities /Total assets \\
\hline & SIZE & Corporate size & The natural logarithm of total assets \\
\hline & ROA & Return on total assets & Net profit/Total assets \\
\hline & $\mathrm{PC}$ & Corporate property & 1 if private enterprise, 0 otherwise \\
\hline & YEAR & Time virtual variable & Control effect of time \\
\hline & INDCD & $\begin{array}{l}\text { Industry virtual } \\
\text { variable }\end{array}$ & Control effect of industry \\
\hline
\end{tabular}

\section{3Model Specification}

To test the hypotheses proposed in this paper, the following multiple regression models are constructed:

(1) $G P M_{i t}=\alpha+\beta_{1} R D_{i t}+\beta_{2} A D_{i t}+\beta_{3} L E V_{i t}+\beta_{4} S I Z E_{i t}+\beta_{5} R O A_{i t}+\beta_{6} P C+\beta_{7} Y E A R+\beta_{8} I N D C D+\varepsilon$

(2) Tobin $_{i, t-1}=\alpha+\beta_{1} R D_{i t}+\beta_{2} A D_{i t}+\beta_{3} L E V_{i t}+\beta_{4} S I Z E_{i t}+\beta_{5} R O A_{i t}+\beta_{6} P C+\beta_{7} Y E A R+\beta_{8} I N D C D+\varepsilon$

(3) $G P M_{i t}=\alpha+\beta_{1} R D_{i t}+\beta_{2} A D_{i t}+\beta_{3} R D_{i t} * A D_{i t}+\beta_{4} L E V_{i t}+\beta_{5} S I Z E_{i t}+\beta_{6} R O A_{i t}+\beta_{7} P C+\beta_{8} Y E A R+\beta_{9} I N D C D+\varepsilon$

(4) Tobin $Q_{i, t-1}=\alpha+\beta_{1} R D_{i t}+\beta_{2} A D_{i t}+\beta_{3} R D_{i t} * A D_{i t}+\beta_{4} L E V_{i t}+\beta_{5} S I Z E_{i t}+\beta_{6} R O A_{i t}+\beta_{7} P C+\beta_{8} Y E A R+\beta_{9} I N D C D+\varepsilon$

We use model1 and 2 to test the relationship between $R \& D$, advertising and enterprises' short-term profitability and long-term value; while the cross term is introduced in model 3 and 4 to check out how the interaction of R\&D and advertising affect short-term profitability and long-term value. The regression coefficients are estimated by using the least square method (LSM).

\section{Empirical Test}

\subsection{Descriptive Statistics}


Descriptive statistics are shown in Table 2. The mean of GPM and Tobin Q indicates a relatively high gross profit margin and market value, but their standard deviation reflects a greater diversity among various enterprises. As RD's mean of 0.064 shows, listed companies in China pay more attention to $R \& D$ expenditure in recent years. In contrast, AD's mean of 0.146 is larger than $R \& D$ intensity, which shows that enterprises place more emphasis on advertising expenditure than $R \& D$ expenditure. The mean of LEV and SIZE is 0.394 and 21.699, but a greater differential in company size, ROA's mean of 0.05 indicates a low level on overall operating.

Table 2Descriptive statistics

\begin{tabular}{cccccc}
\hline Variable & Min & Median & Max & Mean & SD \\
\hline GPM & -0.225 & 0.266 & 0.968 & 0.309 & 0.189 \\
TobinQ & 0.486 & 1.649 & 14.915 & 2.044 & 1.360 \\
RD & 0.000 & 0.030 & 1.267 & 0.064 & 0.121 \\
AD & 0.005 & 0.100 & 9.944 & 0.146 & 0.352 \\
LEV & 0.015 & 0.398 & 1.163 & 0.394 & 0.234 \\
SIZE & 18.679 & 21.508 & 26.528 & 21.699 & 1.221 \\
ROA & -0.404 & 0.044 & 0.381 & 0.050 & 0.054 \\
\hline
\end{tabular}

\subsection{Empirical Results}

Table 3 shows the regression results of Model 1 and 2. In Model 1, RD's regression coefficient is positive and significant at $1 \%$ level, but AD's regression coefficient is not significant. This indicates that $R \& D$ expenditure of listed companies in China has a significant positive promoting effect on short-term profitability, while the effect of advertising expenditure is not significant. In Model 2, RD's regression coefficient didn't pass the significant test, AD's regression coefficient is positive and significant at $1 \%$ level. It shows that advertising expenditure is an important variable positively affecting the long-term value while $R \& D$ expenditure of listed companies in China has no significant effect. Therefore, $\mathrm{H} 1$ is partly validated, i.e., R\&D expenditure has a positive impact on enterprises' short-term profitability and advertising expenditure positively affects enterprises' long-term value. 


\begin{tabular}{|c|c|c|c|c|c|}
\hline \multicolumn{3}{|c|}{ Table 3} & \multicolumn{3}{|c|}{ Table 4} \\
\hline $\begin{array}{c}\text { Independent } \\
\text { Variable }\end{array}$ & $\begin{array}{l}\text { Model } \\
\text { (1) }\end{array}$ & Model(2) & $\begin{array}{c}\text { Independent } \\
\text { Variable }\end{array}$ & Model(3) & Model(4) \\
\hline $\mathrm{RD}$ & $\begin{array}{c}0.269^{* * *} \\
(3.75)\end{array}$ & $\begin{array}{l}-0.377 \\
(-1.71)\end{array}$ & RD & $\begin{array}{l}-0.008 \\
(-0.07)\end{array}$ & $\begin{array}{l}-0.300 \\
(-0.97)\end{array}$ \\
\hline $\mathrm{AD}$ & $\begin{array}{l}0.120 \\
(1.25)\end{array}$ & $\begin{array}{l}0.632^{* *} \\
(2.16)\end{array}$ & $\mathrm{AD}$ & $\begin{array}{l}0.105 \\
(1.29)\end{array}$ & $\begin{array}{l}0.653^{* *} \\
(2.17)\end{array}$ \\
\hline LEV & $\begin{array}{c}-0.254^{* * *} \\
(-6.34)\end{array}$ & $\begin{array}{l}0.871^{* *} \\
(2.29)\end{array}$ & LEV & $\begin{array}{c}-0.234^{* * *} \\
(-5.93)\end{array}$ & $\begin{array}{l}0.867^{* *} \\
(2.27)\end{array}$ \\
\hline SIZE & $\begin{array}{l}0.001 \\
(0.17)\end{array}$ & $\begin{array}{c}-0.377^{* * *} \\
(-5.56)\end{array}$ & SIZE & $\begin{array}{l}-0.000 \\
(-0.02)\end{array}$ & $\begin{array}{c}-0.376^{* * *} \\
(-5.54)\end{array}$ \\
\hline ROA & $\begin{array}{c}1.285^{* * *} \\
(8.94)\end{array}$ & $\begin{array}{c}6.669^{* * *} \\
(3.67)\end{array}$ & ROA & $\begin{array}{c}1.365^{* * *} \\
(9.78)\end{array}$ & $\begin{array}{c}6.657^{* * *} \\
(3.65)\end{array}$ \\
\hline PC & $\begin{array}{c}0.049^{* * *} \\
(3.17)\end{array}$ & $\begin{array}{c}-0.363^{* * *} \\
(-3.10)\end{array}$ & $\mathrm{RD}^{*} \mathrm{AD}$ & $\begin{array}{l}1.525^{*} \\
(1.83)\end{array}$ & $\begin{array}{l}-0.416 \\
(-0.53)\end{array}$ \\
\hline Cons & $\begin{array}{l}-0.658 \\
(-1.53)\end{array}$ & $\begin{array}{c}12.512^{* * *} \\
(9.38)\end{array}$ & PC & $\begin{array}{c}0.045^{* * *} \\
(3.06)\end{array}$ & $\begin{array}{c}-0.363^{* * *} \\
(-3.09)\end{array}$ \\
\hline $\begin{array}{l}\mathrm{N} \\
\mathrm{R}^{2}\end{array}$ & $\begin{array}{c}903 \\
0.555\end{array}$ & $\begin{array}{c}602 \\
0.330\end{array}$ & Cons & $\begin{array}{l}-0.611^{*} \\
(-1.65)\end{array}$ & $\begin{array}{c}12.488^{\text {*** }} \\
(9.28)\end{array}$ \\
\hline & & & $\begin{array}{l}\mathrm{N} \\
\mathrm{R}^{2}\end{array}$ & $\begin{array}{c}903 \\
0.582\end{array}$ & $\begin{array}{c}602 \\
0.330\end{array}$ \\
\hline
\end{tabular}

Note (1) YEAR and INDCD are nominal variables, their regression coefficients are meaningless $(2)^{*} \mathrm{P}<0.1,{ }^{* *} \mathrm{P}<0.5,{ }^{* * *} \mathrm{P}<0.01$

(3) As a result of choosing the Tobin $Q$ that lagged one year, sample size decreased by $1 / 3$

Table 4 shows the regression results of Model 3 and 4,the regression coefficient of RD*AD in Model 3 is positive at the significance level of $10 \%$ after introducing the cross term (RD*AD) of R\&D intensity and advertising intensity, but the regression coefficient of RD*AD in Model 4 is not significant. It indicates that the impacts of $R \& D$ expenditure and advertising expenditure on enterprises' short-term profitability will complement each other, but there are no significant interactive effects on the long-term value. Therefore, $\mathrm{H} 2$ is validated, the interaction of $\mathrm{R} \& \mathrm{D}$ and advertising are positively related to enterprises' short-term profitability without relationship to the long-term value.

\section{Results and Discussion}

This study comes to the following conclusions:

(1)R\&D expenditure may promote enterprises' short-term profitability and advertising expenditure has a significant impact on enterprises' long-term value. We believe that the following reasons lead to this result. First, from enterprises' emphasis on technical innovation and marketing, there is more of an emphasis on advertising than $R \& D$ expenditure of independent innovation. Advertising intensity is more than twice larger than R\&D intensity as far as their mean and R\&D expenditure has a far cry from the requirements of innovative countries. Secondly, there is a short 
sightedness in R\&D expenditure that most enterprises prefer to applied R\&D expenditure which can only promote enterprises' short-term profitability but does little help to form their core competence on technique. Finally, domestic consumers and investors have a high recognition of the enterprise brand. In the case of unsymmetrical information, we know the company or its product and service more from advertising.

(2)Advertising expenditure and R\&D expenditure has an interactive effect on enterprises' short-term profitability. In order to improve the sales of new products and capture market first, listed companies will trade-off between technological innovation and marketing management and generate an interactive effect. However, focusing on practical reforms rather than breakthrough innovations, the interaction of $R \& D$ and advertising is not shown in enterprises' long-term value.

Based on the above conclusion, we give the following suggestions: (1) Promote enterprise innovation combined with interior and exterior. "Interior" depends on enterprises themselves, based on the local market, they should promote autonomous technological innovation competence accordingly and attach great importance to the introduction of technology innovation talents and basic R\&D expenditure when imitating outside intellectual; "Exterior" relies on the government who can guide and encourage enterprises to carry on independent innovation by enforcing intellectual property protections, constructing innovation environment and increasing the tax revenue preferential policy and so on.(2) Take the long view and give play to synergistic effects. Enterprises should try to overcome short-sightedness both in innovative activities and marketing activities, and make enterprise strategy in the light of their development. Innovations are not only embodied in technology, but also in marketing and organizational management. Synergistic effects existed between technological innovation and advertising, so enterprises can build relevant departments to coordinate $R \& D$ and advertising, and bring into play their interaction flexibly.

\section{References}

[1] Andras T L, Srinivasan S S. Advertising intensity and R\&D intensity: Differences across industries and their impact on firm's performance $[\mathrm{J}]$. International Journal of Business and Economics, 2003, 2(2): 81-90.

[2]Cheng D M. The quantitative analysis of the impact of advertising on sales [J]. Statistics and Decision, 2008,22:70-72.

[3]Du Y P, Wang L. The relation between the R\&D expenditure and performance of High-tech growth companies__ based on the empirical study of lifecycle of enterprise[J].Scientific and technological progress and countermeasures,2011,12:83-87.

[4]Huang M L. The relations research between corporate performance and internationalization of Chinese enterprises in a particular strength perspective [M]. Beijing:Economic Science Press, 2006. [5]Jiang Y Q. The research of how real estate companies advertising affects the corporate performance [D].East China Normal University, 2010.

[6]Li T, Huang X B, Wang C. The empirical study of enterprise R\&D expenditure and corporate 
performance_- the comparison of the listed company between information industry and manufacturing industry[J].Science of Science and Management of S\&T, 2008, 07: 170-174. [7]Liu X Y. The impact of enterprise technology innovation and marketing on profitability in GEM [J].Journal of Guangxi university for nationalities(Natural Science) ,2013,05:160-165.

[8]Qin J. Interactive effects of marketing resource and technical resources and new product development of entrepreneurial enterprises [J]. Science of Science and Management of S\&T,2011,02:133-139.

[9]Ren H Y, Shi P. The empirical study of enterprise R\&D expenditure and corporate performance_ _ based on the data analysis of Shanghai A-share manufacturing listed companies[J].Scientific and technological progress and countermeasures,2009,24:89-93. [10]Sun W F, Huang Z H. Advertising expenditure, R\&D expenditure and corporate performance [J]. Management of scientific research,2013,02:44-51.

[11]Tushman M L, Anderson P. Technological discontinuities and organizational environments [J]. Administrative science quarterly, 1986, 1(1): 439-465.

[12]Wang R X. The discussion of intelligence capital input and output: from R\&D expenditure and advertising expenditure[D]. Taiwan: Chaoyang University of Technology,2005.

[13]Xu J Y. The causal research of R\&D and advertising expenditure and the variation in value[M].Taiwan:Tunghai University,2001.

[14]You C. The empirical study of R\&D expenditure and financial performance of China's small and medium-sized enterprises__ based on the panel data of listed companies in SME board[J]. South China Finance,2010,01:52-55+59.

[15]Zhang c. The empirical study of advertising expenditure and auto sales [D]. Soochow University,2011 